\title{
Genetic diversity in peach cultivars
}

Rosana Gonçalves Pires Matias, Cláudio Horst Bruckner, João Alison Alves Oliveira*, Pedro Crescêncio Souza Carneiro, Danielle Fabíola Pereira Silva, Carlos Eduardo Magalhães Santos

Federal University of Viçosa, Viçosa, MG, Brazil

*Corresponding author, e-mail: joao.alison@yahoo.com.br

\begin{abstract}
This study aimed to evaluate the genetic diversity among 28 peach cultivars and two nectarine cultivars, describing the most important characters in the diversity evaluation. The study was developed at the Federal University of Viçosa - Brazil, and the following characteristics were evaluated: fruit mass, suture, equatorial and polar diameters, firmness, soluble solids (SS), titratable acidity (TA), SS/TA, ascorbic acid and carotenoids contents, skin and flesh color (coordinate b* and hue angle - ${ }^{\circ}$ ). Genetic diversity in peach and nectarine cultivars enabled the formation of seven, six and six groups in the 2011, 2012 and 2013 crop years, respectively. The features that most contributed to this diversity were fruit mass, skin and flesh ${ }^{\circ} \mathrm{h}$ and firmness. The greatest genetic divergence was observed between 'Marli' and 'Rubrosol', 'Josefina' and 'Maciel' and 'Maciel' and 'Rubrosol' during the 2011,2012 and 2013 crop years, respectively.
\end{abstract}

Keywords: Prunus persica, variability, breeding

\section{Diversidade genética em cultivares de pessegueiro}

\section{Resumo}

Neste trabalho, objetivou-se avaliar a diversidade genética entre 28 cultivares de pessegueiro e duas cultivares de nectarineira, discriminando os caracteres mais importantes na avaliação da diversidade. Os trabalhos foram desenvolvidos na Universidade Federal de Viçosa, e avaliaram-se as características massa, diâmetros sutural, equatorial e polar, firmeza, teor de sólidos solúveis (SS), acidez titulável (AT), relação SS/AT, teores de ácido ascórbico e de carotenoides e cor da casca e da polpa (coordenada b* e ângulo hue - ${ }^{\circ}$ ). . A diversidade genética nas cultivares de pessegueiro e nectarineira possibilitou a formação de sete, seis e seis grupos, nos ciclos de 2011, 2012 e 2013, respectivamente. As características que mais contribuíram para essa diversidade foram massa de fruto, 'h da casca e da polpa e firmeza. Maior divergência genética foi observada entre 'Marli' e 'Rubrosol', 'Josefina' e 'Maciel' e 'Maciel' e 'Rubrosol', nos anos 2011, 2012 e 2013, respectivamente.

Palavras chave: Prunus persica, variabilidade, melhoramento 


\section{Introduction}

The Southeast Region of Brazil has favorable conditions for economic exploitation of temperate climate fruit trees, mainly due to the high altitude (Ramos \& Leonel, 2008). The advance on peach production, including nectarine, in regions of subtropical and mild winter is, mainly, due to the release of cultivars with low demand in intense cold and the creation of technologies that enable the development of the crop (Leonel \& Tecchio, 2011). Major advances in the peach improvement have been the expansion in the adaptation area, extension of harvest period and the diversification and improvement of fruit quality (Souza et al., 2013).

According to Lima et al. (2011), knowledge about the genetic variability of the species are an essential prerequisite for their preservation and the success of breeding programs. Studies of genetic diversity provide parameters for identifying genitors favorable to the obtention of segregating populations in breeding programs and the obtention of genetically improved populations (Costa et al., 2006). Moreover, it can be useful even in cultivar recommendation for certain regions when the goal is to increase the genetic base of the cultivars that will be reccomended to farmers (Bertan et al., 2007).

Several methods can be used to evaluate genetic diversity, and the choice of each method is based on the accuracy required by the researcher, on the way that the data was obtained and on the simplicity of the techniques (Rodrigues et al., 2010). The multivariate analysis techniques have been routinely used as they consider the evaluated characteristics of the genotypes simultaneously, besides their correlation (Condé et al., 2010). Among the multivariate statistical techniques, the analysis of principal components and by canonical variables and agglomerative methods are included (Cruz et al., 2012).

Agronomic, morphological and molecular characteristics, among others, can be used in genetic diversity quantification (Amorim et al., 2007). The fruit quality is one of the main goals of peach breeding programs, with a direct relationship with market and consumer preferences. In peach, quality refers to obtaining productive plants, with large and firm fruit, with great flavor, color, shape and texture (Wagner Junior et al., 2011).

This study aimed to evaluate the genetic diversity among 28 peach cultivars and two nectarine cultivars, detailing the most important characters in the evaluation of genetic diversity of fruit quality characteristics based on multivariate procedures.

\section{Materials and Methods}

This study was conducted during the 2011 , 2012 and 2013 production cycles, with 28 peach cultivars and two nectarine cultivars from the orchard of the Phytotechny Department of Federal University of Viçosa, in Viçosa, MG, Brazil, $20^{\circ} 45^{\prime} \mathrm{S}$ and $42^{\circ} 51^{\prime} \mathrm{W}$ and at $649 \mathrm{~m}$ altitude (Table 1). The planting took place in October 2008, using as rootstock the 'Okinawa' peach, spaced $5.0 \mathrm{~m}$ between rows and $3.5 \mathrm{~m}$ between plants. Each cultivar was represented by three plants, arranged side by side. All cultural treatments usually recommended for the culture, such as fertilization, pruning, dormancy breaking, hand thinning and irrigation were performed.

The fruits were harvested manually using as criteria the change of background color from green to yellow or creamy white. Thisty fruits of three plants of each cultivar, for subsequent laboratory analysis, were collected. The evaluated characteristicswere fruit mass, suture, equatorial and polar diameters, firmness, soluble solids, titratable acidity, soluble solids and titratable acidity ratio, ascorbic acid content, carotenoids content and flesh and skin color.

The fruit mass (FM), in grams (g), was determined using a digital balance with $0.1 \mathrm{~g}$ of accuracy.

The suture diameter (SD) - the maximum transverse distance of the fruit measured by the distance from suture to the opposite part, the equatorial diameter (ED) - the maximum transverse distance of the fruit, the perpendicular measure to the suture zone - and the polar diameter (PD) - measured by the distance from the peduncle to the apex of the fruit - were measured in $\mathrm{mm}$ using a digital caliper, from Mitutoyo DL-10. 
Table 1. List of cultivars, genealogy, origin, flesh color and botanical variety of cultivars evaluated for fruit quality.

\begin{tabular}{|c|c|c|c|c|c|}
\hline Identification & Cultivar & Genealogy & Origin & Flesh & Bot. variety \\
\hline 1 & Aldrighi & Selection of Rio Grande do Sul & ECT & A & $P$ \\
\hline 2 & Argel & - & - & A & $P$ \\
\hline 3 & Aurora 2 & Open pollination Ouromel-4 & IAC & A & $P$ \\
\hline 4 & Baronesa & (Hawaiia $\times$ Southland)F3 & ECT & A & $P$ \\
\hline 5 & Biuti & Halford-2 $\times$ Rubi & IAC & A & $P$ \\
\hline 6 & Campinas- 1 & Self-pollination of Lake City & IAC & A & $P$ \\
\hline 7 & Capdebosq & Lake City x S56-87 & ECT & A & $P$ \\
\hline 8 & Cerrito & (Lake City x S56-32) F2 & ECT & A & A \\
\hline 9 & Colibri & Self-pollination of Cristal & IAC & B & $P$ \\
\hline 10 & Coral & Delicioso x Interlúdio & ECT & B & $P$ \\
\hline 11 & Cristal & Suber x Pérola de Itaquera & IAC & B & $P$ \\
\hline 12 & Delicioso Precoce & Supermel x Rubrosol & IAC & B & $P$ \\
\hline 13 & Diamante & Convênio x Pelota 77 & ECT & A & $P$ \\
\hline 14 & Elberta & - & ECT & A & $P$ \\
\hline 15 & Flordaprince & Fla 2-7 x Maravilha & Florida & A & $P$ \\
\hline 16 & Jóia 4 & Catita $\times$ Rubrosol & IAC & B & $P$ \\
\hline 17 & Josefina & Open pollination (Ouromel x Rubrosol) & IAC & B & N \\
\hline 18 & Lake City & - & ECT & A & $P$ \\
\hline 19 & Maciel & Conserva 171 x Conserva 334 & ECT & A & $P$ \\
\hline 20 & Marli & (Delicioso x Interlúdio) F2 & ECT & B & $P$ \\
\hline 21 & Minasul & - & - & A & $P$ \\
\hline 22 & Olímpia & Bolinha $\times 7-28$ & ECT & A & $P$ \\
\hline 23 & Pérola de Itaquera & - & - & B & $P$ \\
\hline 24 & Real & Lake City x Rei da Conserva & IAC & A & $P$ \\
\hline 25 & Rei da Conserva & Descoberta em Itaquera (SP) & - & A & $P$ \\
\hline 26 & Rubimel & Chimarrita x Flordaprince & ECT & A & $P$ \\
\hline 27 & Rubrosol & Open pollin. (Southland x Hawaiia)F2 & Florida & A & N \\
\hline 28 & Talismã & Rei da Conserva $x$ Jewel & IAC & B & $P$ \\
\hline 29 & Tropical & Open pollination of IAC 371-2 & IAC & B & $P$ \\
\hline 30 & Tropic Beauty & - & Florida & A & $\mathrm{P}$ \\
\hline
\end{tabular}

The flesh firmness (FIR) was determined on the equatorial region of one of the sides for each fruit, after removal the epidermis, with the aid of a digital penetrometer Effe-Gi, model FT-011 using a $8 \mathrm{~mm}$ diameter tip and the measurements were expressed in Newtons (N).

The soluble solids content of fruits (SS) was analyzed in the juice that was manually extracted from the equatorial region of one side for each fruit, with a digital ATAGO refractometer (Palete PR-101), and the values were expressed in ${ }^{\circ}$ Brix.

The titratable acidity (TA) was determined by titrating $5 \mathrm{~g}$ of the flesh juice with additional $95 \mathrm{ml}$ of distilled water with a $0.1 \mathrm{~N} \mathrm{NaOH}$ solution and the result was expressed in percentage of malic acid.

The relation between soluble solids and titratable acidity (SS/TA) was determined by the ratio between the values obtained for SS and TA.

The ascorbic acid content of the flesh
(AA) was determined by titration with Tillman reagent [2.6 dichlorophenolindophenol (sodium salt) $0.1 \%$ ] according to the methodology described by AOAC (2005), and the results were expressed in $\mathrm{mg}$ of ascorbic acid per $100 \mathrm{~g}$ of flesh.

The carotenoids content (CC) was determined by extraction with cold $80 \%$ acetone and approximately $2 \mathrm{~g}$ of macerated flesh. The absorbance of the extracts were read in a spectrophotometer at wavelengths of $470,646.8$ and $663.2 \mathrm{~nm}$ and the carotenoids content determined by the equations of Lichtenthaler (1987), in $\mu \mathrm{g} \cdot \mathrm{mL}^{-1}$ of the extract, being the results multiplied by 25 and divided by the flesh weight, and expressed as mg/100 g pulp.

The skin and flesh color were evaluated by two readings obtained on the opposite sides of the skin, in the equatorial region of the fruit, and an internal reading in the central region of the flesh. Readings were performed using a Minolta 
colorimeter CR-300. In pattern C.I.E.L*a*b*, the $L^{*}$ coordinate expresses the degree of brightness of the measured color $\left(L^{*}=100=\right.$ white, $L^{*}=0=$ black). The $a^{*}$ coordinate expresses the degree of variation between red and green ( $a^{*}$ more negative $=$ more green, $a^{*}$ more positive $=$ more red), and the $b^{*}$ coordinate expresses the degree of variation between blue and yellow ( $b^{*}$ more negative $=$ more blue, $b^{*}$ more positive $=$ more yellow) and hue angle of color ( $(\mathrm{h})$, which indicates $0^{\circ}=$ red; $90^{\circ}=$ yellow; $180^{\circ}=$ green; and $270^{\circ}=$ blue .

Genetic diversity was evaluated by cluster analysis using the "Unweighted Pair Group Method with Arithmetic Mean - UPGMA," using as dissimilarity measure the standardized mean for the Euclidean distance (Cruz et al., 2012.). The relative contribution of features to the dissimilarity was estimated according to the criteria of Singh (1981).

The Mojena (1977) method was used to determine the optimal number of groups in the dendrogram. This method is a procedure based on the relative size of the levels of mergers (distances) in the dendogram and consists of selecting the number of groups on stage $j$ which first satisfies the following inequality: $\alpha_{j}>\theta_{k}$, where $\alpha_{i}$ is the value of the distances of the mergers levels corresponding to the stage $j(j=1,2, \ldots, n)$, and $\theta_{k}$ is the reference cutoff value expressed by $\theta_{k}=$ $\bar{\alpha}+k \hat{o}_{a}$ where $\bar{\alpha}$ and $k \hat{o}_{a}$ are, respectively, the unbiased estimates of the mean and standard deviation values of $a ; k$ is a constant. Was adopted $k=1.25$ as stopping rule to determine the number of groups, as suggested by Milligan \& Cooper (1985).

The diversity among the accessions was also estimated by multivariate analysis, applying the Tocher optimization method (Cruz et al., 2012).

All statistical analysis were performed using the GENES software (Cruz, 2013).

\section{Results and discussion}

The relative contribution of the characters for the genetic diversity of peach and nectarine cultivars in the forest region of Minas Gerais State is presented in Table 2. The characters adopted in this study can be considered representative, since they were efficient in the dissimilarity analysis and subsequent for the cultivars clustering. In 2011 , the highest rate observed was $25.1 \%$ for the skin ${ }^{\circ} \mathrm{h}$, followed by FM (24.8\%) and FIR (20.2\%). In 2012, the characteristics that most contributed to the genetic diversity of the cultivars were FM, skin ${ }^{\circ} \mathrm{h}$ and flesh ${ }^{\circ} \mathrm{h}$, with values of $27.6 ; 26.2$; and $13.0 \%$, respectively. In 2013, the characteristics FM (43.0\%), FIR (15.03\%) and skin ${ }^{\circ}$ (13.9\%) were the ones that most contributed to the diversity.

In a study with peach populations of the Federal University of Viçosa breeding program, Silva et al. (2014) observed that the variables that contributed the most to the discrimination of populations and formation of groups by clustering methods adopted were the red covering of the epidermis (12.13\%), total titratable acidity (11.66\%) and plants height (11.46\%). In mango, the variables that contributed the most to the discrimination of populations and formation of groups were fruit mass (27.5\%), SS/ TA ratio (13.5\%), transversal diameter (12.3\%) and pulp/endocarp (10.4\%) (Rufini et al., 2011).

By the clustering performed by the hierarchical method "UPGMA" based on the standardized mean for the Euclidean distance, there was the individualization of seven, six and six mutually exclusive groups for the characteristics of fruit mass, suture, equatorial and polar diameters, firmness, soluble solids, titratable acidity, SS/TA ratio, ascorbic acid, carotenoids and skin and flesh color ( $\mathrm{b}^{*}$ and $\left.{ }^{\circ} \mathrm{h}\right)$ of fruits from peach and nectarine cultivars analyzed during the 2011,2012 and 2013 crop years, respectively (Figures 1, 2 and 3).

Analyzing the Figure 1, we can see that the highest number of cultivars were observed in group I, with 14 [3 ('Campinas-1'), 24 ('Real'), 1 ('Aldrighi'), 18 ('Lake City'), 5 ('Biuti'), 14 ('Elberta'), 2 ('Argel'), 7 ('Capdebosq'), 21 ('Minasul'), 25 ('Rei da Conserva'), 22 ('Olímpia'), 8 ('Cerrito'), 13 ('Diamante') and 19 ('Maciel')] from the total of 30 evaluated cultivars, which indicates a small genetic divergence among them. In this same group (I), it was also obtained the highest number of cultivars in the 2012 cycle, with 16 from the 30 evaluated cultivars [7 ('Capdebosq'), 21 ('Minasul'), 2 ('Argel'), 14 ('Elberta'), 25 ('Rei da Conserva'), 5 ('Biuti'), 
Table 2. Relative contribution of characters for genetic diversity (Singh, 1981) of 28 peach cultivars and two nectarine cultivars in Viçosa, MG, Brazil during the 2011, 2012 and 2013 crop years.

\begin{tabular}{|c|c|c|c|c|}
\hline \multirow[b]{2}{*}{ Variable } & \multicolumn{2}{|c|}{2011} & \multicolumn{2}{|c|}{2012} \\
\hline & S.j & Value in \% & S.j & Value in \% \\
\hline Fruit mass (FM) & 284945.2281 & 24.7905 & 331914.8048 & 27.6161 \\
\hline Suture diameter & 21103.00261 & 1.836 & 23948.51381 & 1.9926 \\
\hline Equatorial diameter & 18104.19849 & 1.5751 & 17685.65538 & 1.4715 \\
\hline Polar diameter & 34757.81977 & 3.024 & 29722.38759 & 2.473 \\
\hline Firmness & 231891.7563 & 20.1748 & 95061.01604 & 7.9093 \\
\hline Soluble solids (SS) & 1237.311955 & 0.1076 & 1213.907824 & 0.101 \\
\hline Titratable acidity (TA) & 45.316767 & 0.0039 & 42.609036 & 0.0035 \\
\hline SS/TA & 37029.91625 & 3.2216 & 149211.6108 & 12.4147 \\
\hline Ascorbic acid & 8013.19016 & 0.6972 & 7696.10958 & 0.6403 \\
\hline Carotenoids & 138.51605 & 0.0121 & 164.634384 & 0.0137 \\
\hline Skin b* & 40060.74677 & 3.4853 & 34032.55134 & 2.8316 \\
\hline Skin ${ }^{\circ} \mathrm{h}$ & 288517.5296 & 25.1013 & 314630.9297 & 26.178 \\
\hline Flesh $b^{*}$ & 24527.83246 & 2.1339 & 40305.9121 & 3.3535 \\
\hline \multirow[t]{2}{*}{ Flesh ${ }^{\circ} \mathrm{h}$} & 159041.3264 & 13.8367 & 156259.6491 & 13.0012 \\
\hline & \multicolumn{2}{|c|}{2013} & & \\
\hline Variable & S.j & Value in $\%$ & & \\
\hline Fruit mass (FM) & 619440.8632 & 43.0155 & & \\
\hline Suture diameter & 31304.97613 & 2.1739 & & \\
\hline Equatorial diameter & 30987.28197 & 2.1518 & & \\
\hline Polar diameter & 41034.28001 & 2.8495 & & \\
\hline Firmness & 216418.2212 & 15.0286 & & \\
\hline Soluble solids (SS) & 1615.859142 & 0.1122 & & \\
\hline Titratable acidity (TA) & 41.095514 & 0.0029 & & \\
\hline SS/TA & 109461.5615 & 7.6013 & & \\
\hline Ascorbic acid & 8109.860103 & 0.5632 & & \\
\hline Carotenoids & 83.795965 & 0.0058 & & \\
\hline Skin b* & 25064.5749 & 1.7405 & & \\
\hline Skin ${ }^{\circ} \mathrm{h}$ & 199997.9993 & 13.8884 & & \\
\hline Flesh b* & 51403.17864 & 3.5696 & & \\
\hline Flesh ${ }^{\circ} \mathrm{h}$ & 105077.3901 & 7.2968 & & \\
\hline
\end{tabular}

3 ('Campinas-1'), 24 ('Real'), 1 ('Aldrighi'), 18 ('Lake City'), 30 ('Tropic Beauty'), 26 ('Rubimel'), 29 ('Tropical'), 15 ('Flordaprince'), 3 ('Aurora 2') and 10 ('Coral)'] (Figure 2) and for the 2013 cycle, with 14 [21 ('Minasul'), 25 ('Rei da Conserva'), 22 ('Olímpia'), 7 ('Capdebosq'), 8 ('Cerrito'), 19 ('Maciel'), 3 ('Campinas-1'), 24 ('Real'), 1 ('Aldrighi'), 5 ('Biuti'), 18 ('Lake City'), 14 ('Elberta'), 2 ('Argel') and 13 ('Diamante')] from the 30 evaluated cultivars (Figure 3 ).

There was no clear relation between the groups separation and the origin of the cultivars, according to the crossings realized and the breeding programs that launched the materials (Table 1). Peach breeding programs from the Campinas Agronomic Institute and Embrapa Temperate Climate had the cultivars 'Rei da Conserva', 'Pérola de Itaquera' and 'Taichi' and 'Delicioso Precoce', 'Rosado', 'Admirável', '15 de Novembro' and 'Interlúdio' as founders, with contributions of 33 and $54 \%$, respectively, and the cultivars 'Peento', 'Hawaiian' and 'Strawberry', common to both programs (Byrne, 2003). Also, no difference was detected between groups formation among 17 sunflower cultivars from different breeding programs in relation to Argentine and Brazilian origin (Vogt et al., 2012), as well as the formation of groups of fava beans from different countries, regarding their origin (Carmo et al., 2013).

However, it was observed that there was similarities in the cultivars of the group I during the 2011, 2012 and 2013 crop years and that all of them produce yellow flesh fruits (Table 1), except for 'Tropical' and 'Coral', cultivars with white flesh, that were included in group I of the 2012 cycle (Figure 2). It can also be noted that most white flesh cultivars were allocated to different groups, as in groups III, IV and VI in 2011, in groups III and IV in 2012 and in groups II 


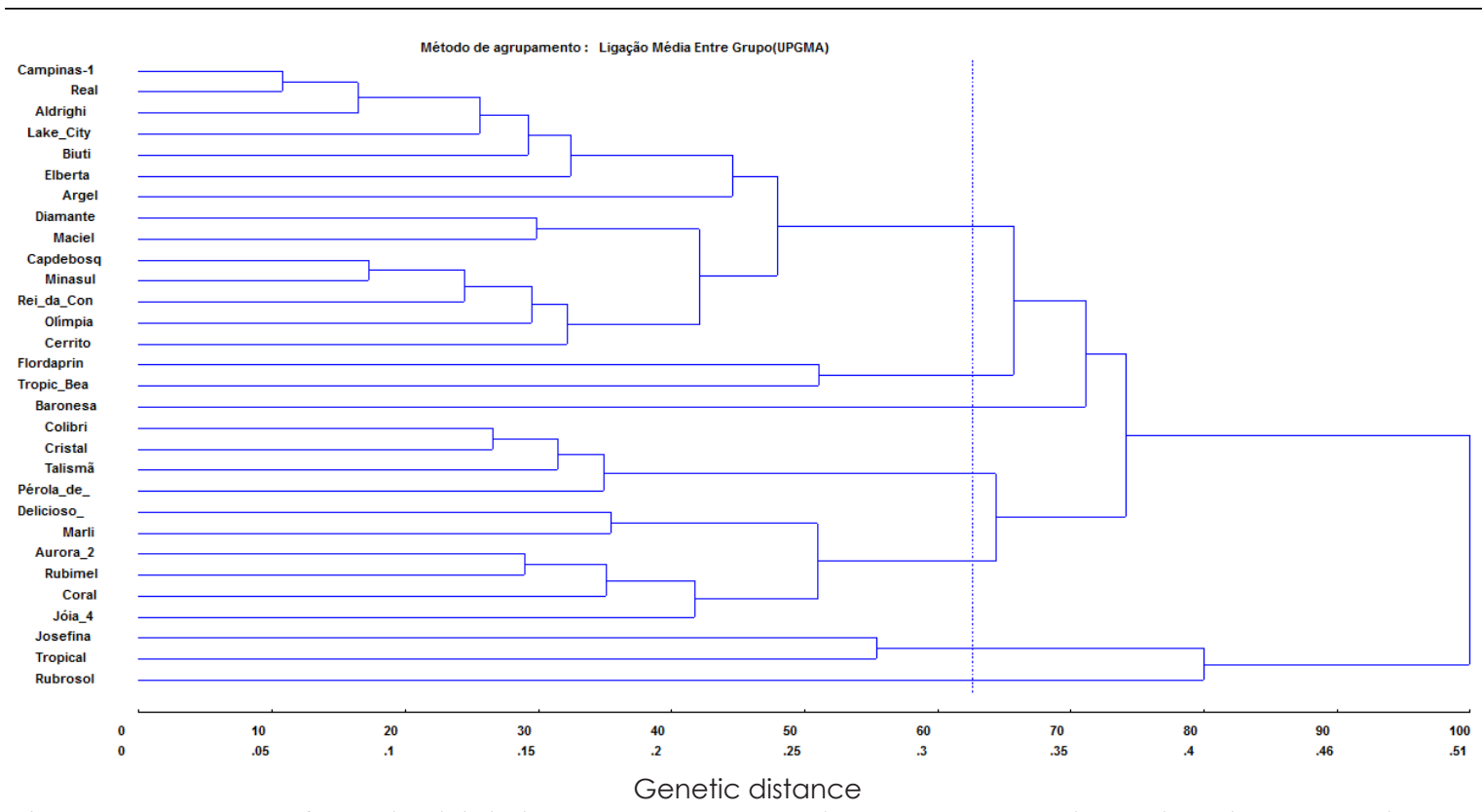

Figure 1. Dendrogram of genetic dissimilarity among 28 peach cultivars and two nectarine cultivars, in 2011 , obtained by "UPGMA" method, based on 14 characters, using the standardized mean for the Euclidean distance. The percentages of distances between the cultivars were represented in the $X$ axis and the 30 cultivars were represented in the $Y$ axis.

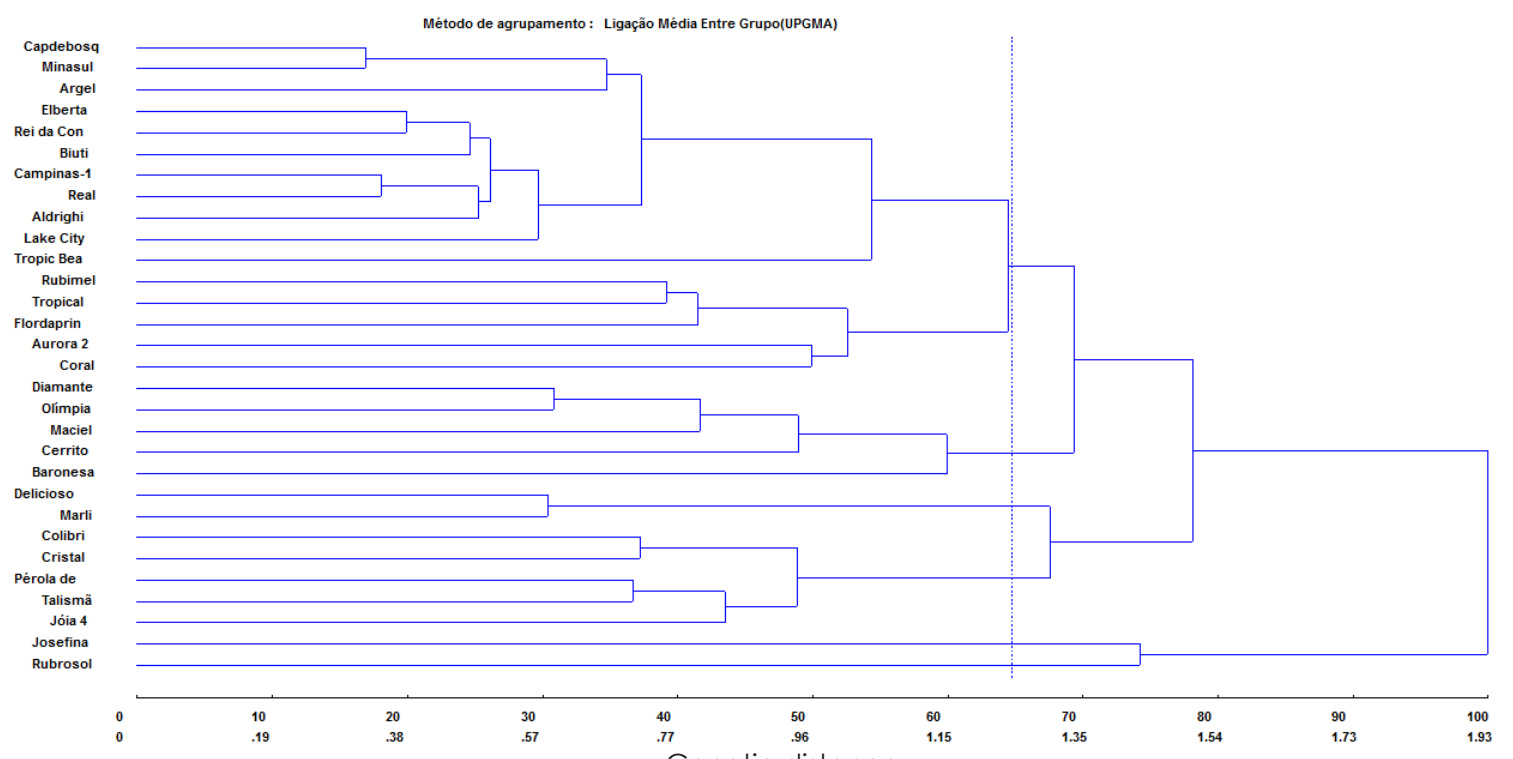

Figure 2. Dendrogram of genetic dissimilarity among 28 peach cultivars and two nectarine cultivars, in 2012, obtained by "UPGMA" method, based on 14 characters, using the standardized mean for the Euclidean distance. The percentages of distances between the cultivars were represented in the $X$ axis and the 30 cultivars were represented in the $Y$ axis.

and IV in 2013. In addition, there was a clustering tendency based on the fruit mass, as can be seen in the 2012 dendogram (Figure 2), where in group II are cultivars with yellow pulp fruit with higher average mass, and groups III, IV and V consist of cultivars with white pulp fruit. However, in group III is possible to observe the cultivars 'Delicioso Precoce' and 'Marli', that among white flesh fruits are the ones that have greater mass; and in group 5 the nectarine 'Josefina', which are usually small and, therefore, have low mass, confirming the relative contribution of this features to the formation of the groups (Table 2).

For the 2011 cycle, the greatest difference was obtained between the cultivars 'Marli' (20) and 'Rubrosol' (27), belonging to the groups IV and VII (Figure 1). For the 2012 cycle, cultivars 'Josefina' (17) and 'Maciel' (19) were the most divergent, being from groups $V$ and II (Figure 2). In the 2013 cycle, the greatest difference was between 'Maciel' (19) and 'Rubrosol' (27), belonging to groups I and VI (Figure 3). 
Since the evolution of species occurs, genetic variability is essential for natural selection, and it is in populations with genetic variability that the selection of plants occur with desirable agronomic characteristics, such as larger and tastier fruits and with resistance to diseases and insects (Wagner Júnior et al. 2011). The use of parental genotypes with the greatest possible divergence is important to maximize heterosis in hybrids, to increase the likelihood of superior segregants in advanced generations and to increase the genetic base (Li et al., 2013; Verde et al., 2013).

Genetic diversity in peach and nectarine cultivars enabled the formation of distinct groups in the three evaluation cycles and the evaluated characteristics that contributed the most to genetic divergence were fruit mass, skin ${ }^{\circ} \mathrm{hl}$, flesh ${ }^{\circ} \mathrm{h}$ and flesh firmness. Greatest divergence was observed between 'Marli' and 'Rubrosol', 'Josefina' and 'Maciel' and 'Maciel' and 'Rubrosol', in the years 2011, 2012 and 2013, respectively. This shows more heterotic potential in these three combinations. However, it is important to highlight that 'Rubrosol' and 'Josefina' are two nectarine trees that produce small fruits with low weight, but whose fruits have reddish epidermis, and 'Josefina' has a high soluble solids and titratable acidity ratio.

The grouping promoted by the Tocher's method based on Euclidean genetic distances resulted in four mutually exclusive groups (Table 3). The group I was formed by 27 peach cultivars, gathering $90 \%$ of genotypes. Group II was composed of the peach cultivar Marli, while Group III and IV were represented respectively by the nectarine cultivars and Josefina Rubrosol. Based on the results it is recommended in a breeding program, the crossing of different genotypes groups, so that there is a higher heterosis in their hybrids.

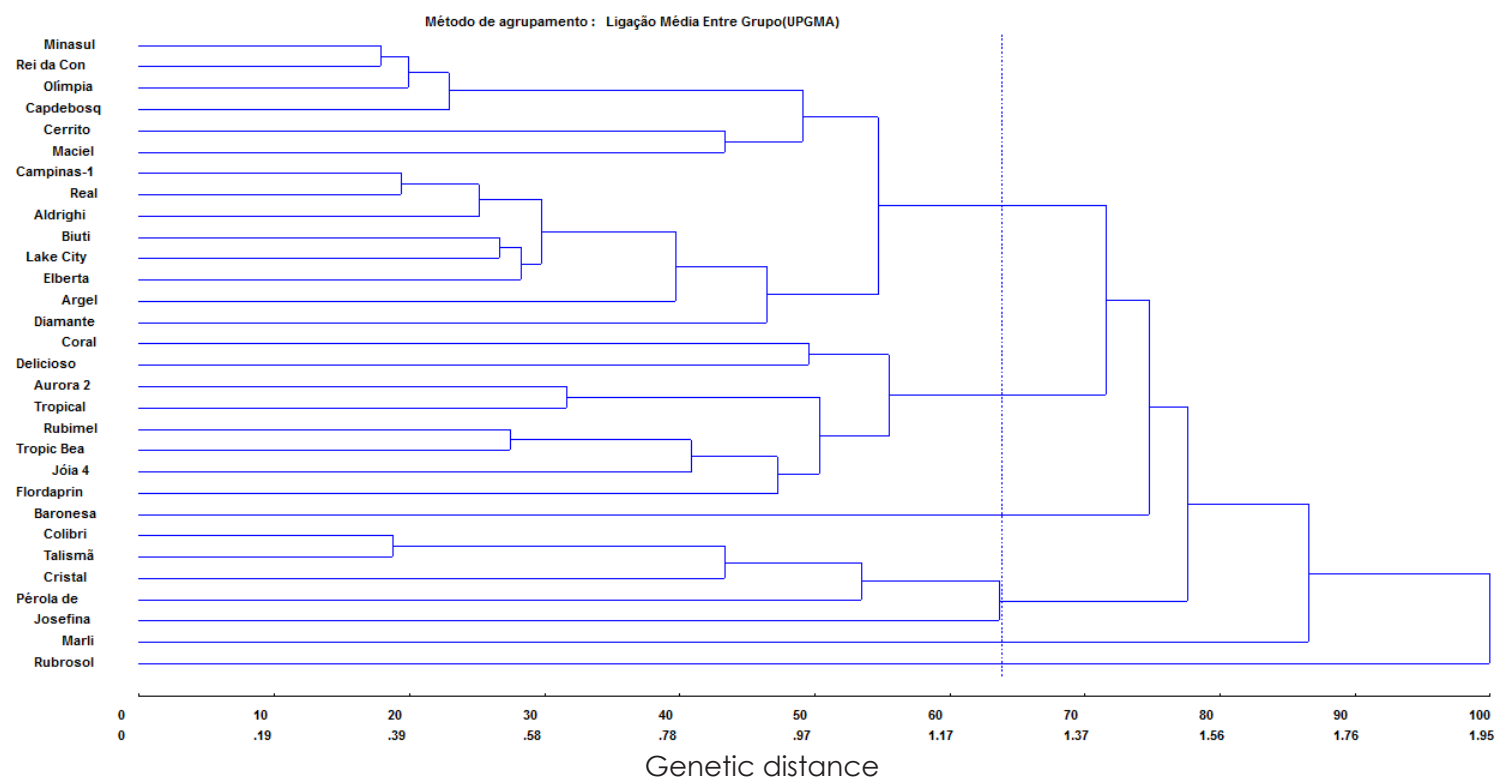

Figure 3. Dendrogram of genetic dissimilarity among 28 peach cultivars and two nectarine cultivars, in 2013 , obtained by "UPGMA" method, based on 14 characters, using the standardized mean for the Euclidean distance. The percentages of distances between the cultivars were represented in the $X$ axis and the 30 cultivars were represented in the $Y$ axis.

Table 3. Genotyoes groups by the optimization method of Tocher, for 28 peach cultivars and two nectarine cultivars in Viçosa, MG, Brazil, for the 2011,2012 and 2013 production cycles based on 14 characters, using the standardized mean to calculate the Euclidean distance.

\begin{tabular}{cl}
\hline Groups & \multicolumn{1}{c}{ Genotypes } \\
\hline & Capdebosq, Minasul, Rei_da Conserva, Olímpia, Elberta Cerrito, Campinas-1, Real, Aldrighi, Biuti, \\
I & Lake City, Diamante, Argel, Maciel, Coral, Rubimel, Tropic Beauty, Flordaprince, Baronesa, Aurora \\
& 2, Talismã, Pérola de Itaquera, Delicioso Precoce, Jóia 4, Cristal, Colibri, Tropical \\
II & Marli \\
III & Josefina \\
IV & Rubrosol \\
\hline
\end{tabular}




\section{Conclusions}

Genetic diversity in peach and nectarine cultivars enabled the formation of distinct groups in the three evaluation cycles and regarding the evaluated characteristics, the ones that contributed the most to genetic divergence were fruit mass, skin ${ }^{\circ} \mathrm{h}$, flesh ${ }^{\circ} \mathrm{h}$ and flesh firmness. Greatest divergence was observed between 'Marli' and 'Rubrosol', 'Josefina' and 'Maciel' and 'Maciel' and 'Rubrosol', during the 2011, 2012 and 2013 crop years, respectively. This represents more heterotic potential in these three combinations. However, it is important to highlight that 'Rubrosol' and 'Josefina' are two nectarine trees that produce small fruits and, therefore, low mass fruits, but whose fruits have reddish epidermis, and 'Josefina' has a high ratio of soluble solids and titratable acidity.

\section{Acknowledgments}

To the National Counsel of Technological and Scientific Development (CNPq), the Coordination for the Improvement of Higher Education Personnel (CAPES) and the Minas Gerais State Research Foundation (FAPEMIG) for the financial support.

\section{References}

Amorim, E.P., Ramos, N.P., Ungaro, M.R.G., Kiihl, T.A.M. 2007. Diversidade genética em genótipos de girassol. Ciência e Agrotecnologia 31: $1637-$ 1644.

AOAC. Association of The Official Analytical Chemists International. 2005. Official methods of analysis of the Association of the Official Analytical Chemists International. 18 th ed. Gaithersburg, Maryland.

Bertan, I., Vieira, E.A., Carvalho, F.I.F., Oliveira, A.C., Scheeren, P.L., Olivo, F. 2007. Variabilidade genética em trigo aferida por meio da distância genealógica e morfológica. Scientia Agraria 8: 67-74.

Byrne, D.H. 2003. Founding clones of low chilling fresh market peach germplasm developed in the USA and Brazil. Acta Horticulturae 606: 17-21.

Carmo, M.D.S., Gomes, R.L.F., Lopes, A.C.A., Penha, J.S., Gomes, S.O., Assunção Filho, J.R. 2013. Variabilidade genética em subamostras de feijão-fava de crescimento determinado. Crop Breeding and Applied Biotechnology 13: 158-164.

Condé, A.B.T., Coelho, M.A.O., Fronza, V.,
Souza, L.V. 2010. Divergência genética em trigo de sequeiro por meio de caracteres morfoagronômicos. Revista Ceres 57: 762-767.

Costa, M.N., Pereira, W.E., Bruno, R.L.A., Freire, E.C., Nóbrega, M.B.M., Milani, M., Oliveira, A.P. 2006. Diversidade genética entre acessos e cultivares de mamoneira por meio de estatística multivariada. Pesquisa Agropecuária Brasileira 41: 1617-1622.

Cruz, C.D. 2013. GENES - A software package for analysis in experimental statistics and quantitative genetics. Acta Scientiarum. Agronomy 35: 271-276.

Cruz, C.D., Regazzi A.J., Carneiro, P.C.S. 2012. Modelos biométricos aplicados ao melhoramento genético. Editora UFV, Viçosa, Brasil. $514 \mathrm{p}$.

Li, X., Meng, X., Jia, H., Yu, M., Ma, R., Wang, L., Cao, K., Shen, Z. Niu, L., Tian, J., Chen, M., Xie, M., Arus, P., Gao, Z. Aranzana, M.J. 2013. Peach genetic resources: diversity, population structure and linkage disequilibrium. BMC Genetics 14: 84100.

Leonel, S., Tecchio, M.A. 2011. Produção e sazonalidade de pessegueiro e nectarineira sob florescimento espontâneo e com cianamida hidrogenada e óleo mineral. Revista Brasileira de Fruticultura E: 227-234.

Lichtenthaler, H.K. 1987. Chlorophylls and carotenoids: pigments of photosynthetic biomembranes. Methods in Enzymology 148: 349382.

Lima, A.T.B., Souza, V.A.B., Gomes, R.L.F., Lima, P.S.C. 2011. Molecular characterization of cajá, Spondias mombin (Anacardiaceae), by RAPD markers. Genetics and Molecular Research 10: 2893-2904.

Milligan, G.W., Cooper, M.C. 1985. An examination of procedures for determining the number of clusters in a data set. Psychometrika 50: 159-179.

Mojena, R. 1977. Hierarchical grouping methods and stopping rules: an evaluation. The Computer Journal 20: 359-363.

Ramos, D.P., Leonel, S. 2008. Características dos frutos de cultivares de pessegueiros e de nectarineira, com potencial de cultivo em Botucatu, SP. Bioscience Journal 24: 10-18.

Rodrigues, H.C.A., Carvalho, S.P., Carvalho, A.A., Carvalho Filho, J.L.S., Custódio, T.N. 2010. Avaliação da diversidade genética entre acessos de mamoneira (Ricinus communis L.) por meio de caracteres morfoagronômicos. Revista Ceres 57: 773-777. 
Rufini, J.C.M. Galvão, E.R., Prezotti, L., Silva, M.B., Parrela, R.A.C. 2011. Caracterização biométrica e físico-química dos frutos de acessos de manga 'Ubá'. Revista Brasileira de Fruticultura 33: 456464.

Souza, F.B.M., Alvarenga, A.A., Pio, R., Gonçalves, E.D., Patto, L.S. 2013. Produção e qualidade dos frutos de cultivares e seleções de pessegueiro na Serra da Mantiqueira. Bragantia 72: 133-139.

Singh, D. 1981. The relative importance of characters affecting genetic divergence. The Indian Journal of Genetics e Plant Breeding 41: 237-245.

Silva, J.O.C., Cremasco, J.P.G., Matias, R.G.P., Silva, D.F.P., Salazar, A.H., Bruckner, C.H. 2014. Divergência genética entre populações de pessegueiro baseada em características da planta e do fruto. Ciência Rural 44: 1770-1775.

Verde, I., Abbott, A.G., Scalabrin, S., Jung, S., Shu,S., Marroni, F., Zhebentyayeva, T., Dettori, M.T., Grimwood, J., Cattonaro, F., Zuccolo, A., Rossini, L., Jenkins, J., Vendramin, E., Meisel, L.A., Decroocq, V., Sosinski,B., Prochnik, P., Mitros, T., Policriti, A., Cipriani, G., Dondini, L., Ficklin, S., Goodstein, D.M., Xuan, P., Fabbro, C.Del., Aramini, V., Copetti, D., Gonzalez, S., Horner, D.S., Falchi, R., Lucas, S., Mica, E., Maldonado, J., Lazzari, B., Bielenberg, D., Pirona, R., Miculan, M., Barakat, A., Testolin, R., Stella, A., Tartarini, S., Tonutti, P., Arús, P., Orellana, A., Wells, C., Main, D., Vizzotto, G., Silva, H., Salamini, F., Schmutz, J., Morgante, M., Rokhsar, D.S. 2013. The highquality draft genome of peach (Prunus persica) identifies unique patterns of genetic diversity, domestication and genome evolution. Nature Genetics 45: 487-494.

Vogt, G.A., Balbinot Junior, A.A., Souza, A.M. 2012. Diversidade fenotípica em genótipos de girassol. Revista de Ciências Agroveterinárias 11: 26-34.

Wagner Junior, A., Bruckner, C.H., Cantín, C.M., Sanchez, M.A.M., Cruz, C.D. 2011. Diversidade genética entre progênies de pessegueiro em Zaragoza, Espanha. Revista Brasileira de Fruticultura 33: 303-310. 